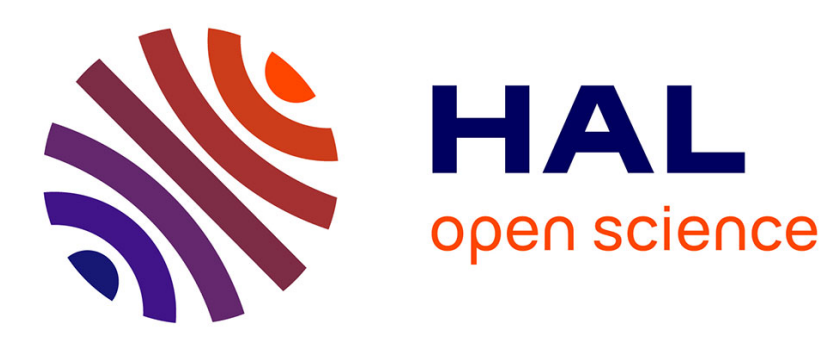

\title{
Bioelectrocatalytic carbon ceramic gas electrode for reduction of dioxygen and its application in a zinc-dioxygen cell
}

Wojciech Nogala, Anna Celabanska, Gunther Wittstock, Marcin Opallo

\section{- To cite this version:}

Wojciech Nogala, Anna Celabanska, Gunther Wittstock, Marcin Opallo. Bioelectrocatalytic carbon ceramic gas electrode for reduction of dioxygen and its application in a zinc-dioxygen cell. Fuel Cells, 2010, 10 (6), pp.1157. 10.1002/fuce.201000083 . hal-00576251

\section{HAL Id: hal-00576251 \\ https://hal.science/hal-00576251}

Submitted on 14 Mar 2011

HAL is a multi-disciplinary open access archive for the deposit and dissemination of scientific research documents, whether they are published or not. The documents may come from teaching and research institutions in France or abroad, or from public or private research centers.
L'archive ouverte pluridisciplinaire HAL, est destinée au dépôt et à la diffusion de documents scientifiques de niveau recherche, publiés ou non, émanant des établissements d'enseignement et de recherche français ou étrangers, des laboratoires publics ou privés. 


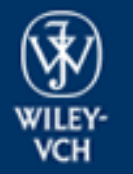

Fuel Cells

VCH

\section{Bioelectrocatalytic carbon ceramic gas electrode for reduction of dioxygen and its application in a zinc-dioxygen cell}

\begin{tabular}{|r|l|}
\hline Journal: & Fuel Cells \\
\hline Manuscript ID: & fuce.201000083.R2 \\
\hline Wiley - Manuscript type: & Original Research Paper \\
\hline Date Submitted by the \\
Author: & 28 -Jun-2010 \\
\hline Complete List of Authors: & $\begin{array}{l}\text { Nogala, Wojciech; Intitute of Physical Chemistry, Electrode } \\
\text { Processes } \\
\text { Celabanska, Anna; Intitute of Physical Chemistry, Electrode } \\
\text { Processes } \\
\text { Wittstock, Gunther; University of Oldenburg, Pure and Applied } \\
\text { Chemistry } \\
\text { Opallo, Marcin; Intitute of Physical Chemistry, Electrode Processes }\end{array}$ \\
\hline Keywords: & $\begin{array}{l}\text { Oxygen Reduction Reaction, Cathode, Cyclic Voltammetry, Gas } \\
\text { Diffusion Electrode, Hybrid }\end{array}$ \\
\hline
\end{tabular}

\section{今 ScholarONE \\ Manuscript Central}


2

\section{Bioelectrocatalytic carbon ceramic gas electrode for reduction of 2 dioxygen and its application in a zinc-dioxygen cell}

3

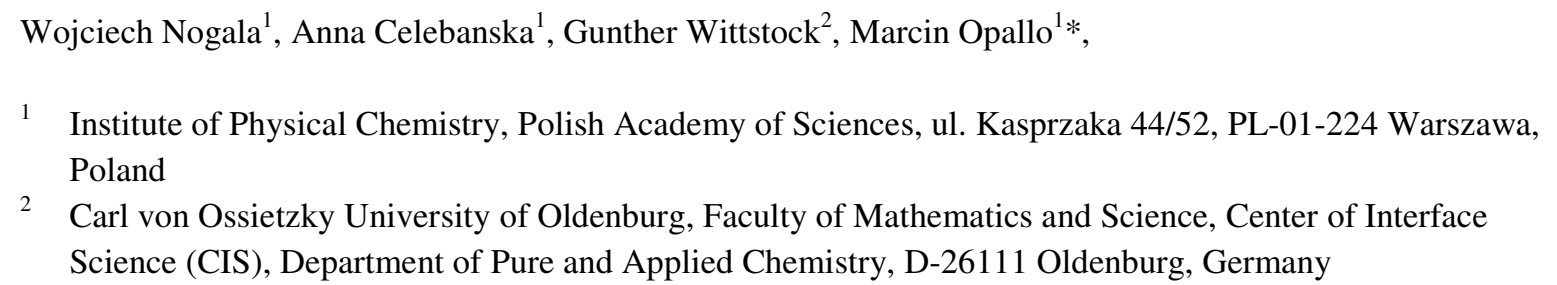

\section{Abstract}

An enzyme-modified carbon ceramic electrode was constructed and studied that is capable to reduce dioxygen supplied from the gas phase. The permeation of the electrode material and its hydrophobic silicate component was studied by scanning electrochemical microscopy. The mass-transfer coefficient of dioxygen in metyltrimethoxysilane-based silicate was estimated to be $6.44 \times 10^{-5} \mathrm{~cm}^{2} \mathrm{~s}^{-1}$. After modification of the electrode with bilirubin oxidase and immersion in deareated aqueous electrolyte, the dioxygen bioelectrocatalytic reduction is observed with onset potential at $0.45 \mathrm{~V}$. The constructed electrode was successfully applied as cathode in a zinc-dioxygen cell.

Keywords: Bilirubin oxidase; Biocatalysis; Electroreduction; Oxygen; Oxygen permeability; Scanning electrochemical microscopy (SECM); Silicate; Sol-gel processes; Zinc; 
28 Carbon ceramic electrodes (CCE) were developed in the early 1990's [1]. They consist of dispersed carbon 29 particles embedded in a silicate matrix. This hybrid material is produced by a sol-gel process followed by drying. 30 The most typical example of CCE, prepared for the use in aqueous electrolyte is obtained by sol-gel processing 31 of methyltrimethoxysilane (MTMOS) mixed with carbon microparticles [2]. Methyl groups attached to the 32 33 silicate network render the pores of the material hydrophobic. Consequently the electrode body is not flooded when immersed into an aqueous solution. Moreover, the porous electrode material can be penetrated by dioxygen up to the matrixlaqueous electrolyte interface inside the electrode body. This property was exploited by the Lev group for preparation carbon ceramic gas electrodes (CCGE) exhibiting dioxygen reduction electrocatalysis with the help of immobilised porphyrins or redox polymer catalyst [3-7]. Bioelectrocatalytic CCE for the reduction of dioxygen dissolved in aqueous solutions has already been reported [8-11]. Here we combine for the first time the biocatalytic dioxygen reduction with an air-breathing CCE.

The construction of dioxygen-permeable biocathode and its application in biofuel cells was recently proposed [12-15], because dioxygen flux through porous electrode can be superior to $\mathrm{O}_{2}$ diffusion in electrolyte and higher current densities can be obtained [12]. Additionally, it allows using dioxygen-free electrolytes which improves the operation of some devices. For example, in dioxygen-glucose biofuel cells [16-18], electron transfer to the anode from the mostly employed anode biocatalyst - glucose oxidase competes with electron acceptance by dioxygen dissolved in the electrolyte [19]. This is not the case in ethanol-dioxygen biofuel cell [20]. Supply of dioxygen from outer gas phase eliminates this problem. Moreover, if both cathodic and anodic biocatalysts are immobilized on the electrodes, the use of dioxygen free electrolyte allows for construction of simpler membranefree devices. This is also important for the recently proposed hybrid zinc-dioxygen cell consisting of a fuel-cell type cathode and a zinc anode [21-23]. The latter is coated by a polymer to prevent zinc oxidation by dioxygen dissolved in electrolyte, i.e. the oxygen corrosion of zinc [24].

In this work we prepared and studied CCGE modified with bilirubin oxidase (BOx) that make use of dioxygen from the gas phase (Scheme 1). The applied enzyme [25] belongs to the family of copper oxidoreductases and is one of the best candidates for dioxygen electroreduction, because it catalyses 4-electrons process. Earlier studies reported $\mathrm{T}_{1}$ redox potential of BOx isolated from Myrothecium verrucaria to be equal $0.29 \mathrm{~V} v \mathrm{vs}$. $\mathrm{AglAgCl}[26]$, whereas later studies provides higher value $-0.49 \mathrm{~V}$ vs. $\mathrm{Ag} \mid \mathrm{AgCl}$ [27]. Although the dioxygen electroreduction overpotential for this enzyme is higher than that of high potential laccase [28], BOx is superior in terms of activity under simulated physiological conditions, i.e. at neutral $\mathrm{pH}$ and in the presence of $\mathrm{Cl}^{-}$anions [29]. Recently, we have shown that CCE modified with adsorbed BOx exhibits efficient mediatorless dioxygen reduction electrocatalysis [9] and the efficiency of this process is increased by addition of hydrophilic carbon nanoparticles (CNPs) to the electrode material. Therefore, we examined CCGE doped with $20 \%$ of CNPs .

Scanning electrochemical microscopy (SECM) [30, 31] is already well estabilished method for determination of local activity of flat surfaces. It is an useful tool for the examination of dioxygen transport through phospholipid monolayers at interfaces [32, 33], artificial membranes [34, 35], cartilage [36, 37] and living cells respiration $[38,39]$. Here the technique is used for imaging of lateral distribution of the electrical conductivity and dioxygen permeability of the CCGE. These experiments were supplemented by SECM examination of dioxygen permeability through a microhole filled with MTMOS-based silicate. Bioelectrocatalytic activity of the electrode towards dioxygen supplied from the gas phase to the back side of the electrode was examined by cyclic voltammetry. This electrode was applied as biocathode in a zinc-dioxygen cell with a bare zinc anode and deaerated electrolyte. Current-voltage characteristics of this cell were determined using chronopotentiometry.

\section{$692 \quad$ Experimental}

\section{$70 \quad 2.1$ Materials}

71 Methyltrimethoxysilane (MTMOS, 98\%), was purchased from Aldrich. $\mathrm{Na}_{2} \mathrm{HPO}_{4}, \mathrm{NaH}_{2} \mathrm{PO}_{4}, \mathrm{~K}_{4}\left[\mathrm{Fe}(\mathrm{CN})_{6}\right] \cdot 3 \mathrm{H}_{2} \mathrm{O}$ 72 and $\mathrm{HCl}(35 \%)$ were from $\mathrm{POCH}$. $\mathrm{Na}_{2} \mathrm{HPO}_{4}$ and $\mathrm{NaH}_{2} \mathrm{PO}_{4}$ were used to prepare $0.1 \mathrm{M}$ buffers. Graphite powder 73 (MO-300, average particle size $20 \mu \mathrm{m}$ ) was purchased from Carbon GmbH. Carbon nanoparticles with 
phenylsulfonic acid surface functionalities (ca. $7.8 \mathrm{~nm}$ mean diameter, Emperor 2000) were obtained from Cabot $\mathrm{cm})$. Argon and (99.9\%) dioxygen (99.9\%) were purchased from Multax. Bilirubin oxidase from Myrothecium sp. (EC 1.3.3.5) was kindly donated by Amano Enzyme Inc. Zinc wire $(250 \mu \mathrm{m}$ in diameter) was from GoodFellow.

\subsection{Procedures}

The hydrophobic sol-gel matrix was prepared as already described [1]. The hydrolyzed sol was obtained by mixing $500 \mu \mathrm{L}$ of MTMOS with $750 \mu \mathrm{L}$ of methanol. After addition of $25 \mu \mathrm{L}$ of $11 \mathrm{M} \mathrm{HCl}$, it was sonicated for $2 \mathrm{~min}$. Afterward, $500 \mathrm{mg}$ of graphite microparticles and $125 \mathrm{mg}$ of CNPs were added and the obtained mash was sonicated for another minute. It was then immediately placed into the $5.7 \mathrm{~mm}$ inner diameter glass tube to fill it to $3 \mathrm{~mm}$ in depth. After drying at room temperature for at least $48 \mathrm{~h}$, it was polished with printing paper, rinsed with water and dried. The geometric surface area of the exposed disc was $0.255 \mathrm{~cm}^{2}$. The electrodes were immersed in $1 \mathrm{~g} \mathrm{~L}^{-1}$ solution of BOx in $0.1 \mathrm{M}$ phosphate buffer $\mathrm{pH} 5.0$ at $+4{ }^{\circ} \mathrm{C}$ for $2 \mathrm{~h}$ and rinsed with water. For determination of dioxygen permeability of MTMOS-based silicate a hole (c.a. $100 \mu \mathrm{m}$ diameter) in $0.8 \mathrm{~mm}$ thick polystyrene (PS) plate (Petri dish, Carl Roth $\mathrm{GmbH}$ ) was burned using a homemade $800 \mathrm{~nm}$ wavelength laser $(100 \mathrm{fs}, 300 \mu \mathrm{J}$ pulses, repetition rate $1 \mathrm{kHz}$ ) during $0.5 \mathrm{~s}$. The hole was filled only with MTMOS-based sol by touching its droplet and left for drying at room temperature for at least $48 \mathrm{~h}$.

SECM experiments were performed with a CHI 900B (CH Instruments) with disk-shaped Pt ultramicroelectrode (UME), Pt wire and $\mathrm{Ag}|\mathrm{AgCl}| \mathrm{KCl}_{\text {sat. }}$ as working, auxiliary and reference electrodes respectively. The UME was obtained by sealing a $\mathrm{Pt}$ wire $(10 \mu \mathrm{m}$ diameter, Goodfellow $\mathrm{GmbH})$ into borosilicate glass capillaries (Hilgenberg $\mathrm{GmbH}$ ). Its apex was shaped according to literature procedure [40]. Optical micrographs were taken using Nikon Eclipse LV150 microscope with LU Plan 10x objective (Nikon). All experiments were carried out at ambient temperature and pressure. The in-house developed package MIRA was used for data analysis [41]. Cyclic voltammetry (CV) was performed with an Autolab PGSTAT 30 (Eco Chemie) electrochemical system with dedicated software in a conventional three electrode cell with a $\mathrm{Pt}$ wire $(0.5 \mathrm{~mm}$ diameter $)$ and a $\mathrm{Ag}|\mathrm{AgCl}| \mathrm{KCl}_{\text {sat. }}$ as auxiliary and reference electrode respectively.

Current density-voltage characteristics of the $\mathrm{Zn}-\mathrm{O}_{2}$ cell were determined by chronopotentiometry. The studied cell acts as an active element of the electric circuit and the galvanostat is a passive element which allows the current to flow with a certain setpoint value. The cell voltage for each current setpoint was recorded $100 \mathrm{~s}$ after current setting. It was observed that after this period the voltage was stabilized. Then the galvanostat acts as resistor with voltmeter and ammeter and results are comparable to those obtained by variable resistor method. The advantage of chronopotentiometry is that it is fully automated. All experiments were performed in deaerated electrolytes and argon was passed above the cells.

\section{Results and discussion}

Earlier studies of nanoparticulate electrodes [12,13] indicates that the transport of dioxygen remains the rate determining step of the mediatorless bioelectrocatalysis. Therefore permeation of dioxygen trough porous MTMOS-based silicate matrix, being the gas permeable CCGE component is a crucial factor. In order to visualize and estimate dioxygen permeability of this silicate material a hole (ca. $150 \mu \mathrm{m}$ in diameter) in $0.8 \mathrm{~mm}$ thick polystyrene plate filled with this material was studied by SECM. In order to provide the most shallow depth of field the topography of the sample was characterized by optical microscopy with totally opened aperture. Both silicate and polystyrene are at the same distance from objective of microscope, because the micrograph is well focused on both materials (Fig. 1). This is also observed from the opposite side of the sample (not shown). Therefore, one may conclude that the entire hole is filled with sol-gel processed silicate. Only two polystyrene hills extend out of the focal plane. This is probably caused by a distorted laser beam focused using a $100 \mathrm{~mm}$ converging lens during manufacturing, because the incident beam is not perfectly parallel to the optical axis of the lens accentuating coma and astigmatism. The height of these topographic defects is ca. $6 \mu \mathrm{m}$ as estimated using optical microscopy. These features are difficult to remove by polishing of the tiny polymer plate. Therefore, we decided to use them for SECM experiments bearing in mind that they can affect the obtained currents. 
Initially SECM imaging were performed in aqueous $\mathrm{K}_{4}\left[\mathrm{Fe}(\mathrm{CN})_{6}\right]$ solution with the microelectrode polarized at $+0.5 \mathrm{~V}$ to achieve a diffusion-controlled oxidation of $\left[\mathrm{Fe}(\mathrm{CN})_{6}\right]^{4-}$ (Fig. 2A). The microelectrode current does not depend on the microelectrode position except for the two small hills of polystyrene mentioned above. Over these spots the current decrease due more efficient blocking of the diffusion of the $\left[\mathrm{Fe}(\mathrm{CN})_{6}\right]^{4-}$ to the microelectrode above the impermeable elevated structures. The lack of any current difference between the position of the hole (between the hills) and the surrounding PS plate indicates that the hole is completely filled with silicate.

130 Subsequently, an image was recorded after the microelectrode potential had been switched to $-0.4 \mathrm{~V}$ in order to achieve diffusion-controlled dioxygen reduction at the Pt UME (Fig. 2B):

$\mathrm{O}_{2}+4 \mathrm{H}^{+}+4 \mathrm{e}^{-} \rightarrow 2 \mathrm{H}_{2} \mathrm{O}$

133 A larger cathodic current is observed over the silicate filled hole (Fig. 2B) indicating that dioxygen concentration

134 is higher comparing to other parts of the sample surface. This indicates the ingress of dioxygen from the 135 backside of the gel-closed hole into the deaerated electrolyte.

136 In order to estimate dioxygen concentration above the silicate and the dioxygen flux, a cross section above the 137 centre of the silicate has been extracted from a SECM image (Fig. 3). The resulting profile has been fitted to the 138 following equations:

$139 i_{\mathrm{T}}=4 n F D\left(\mathrm{O}_{2}\right) r_{\mathrm{T}}\left[\mathrm{O}_{2}\right]_{\mathrm{S}} \zeta$

$$
\zeta=\frac{2}{\pi} \arctan \frac{\sqrt{2} r_{\mathrm{S}}}{\sqrt{\left(\Delta x^{2}+d^{2}-r_{\mathrm{S}}^{2}\right)+\sqrt{\left(\Delta x^{2}+d^{2}-r_{\mathrm{s}}^{2}\right)^{2}+4 d^{2} r_{\mathrm{s}}^{2}}}}
$$

141 These equations were developed for diffusion at an isolated disk-shaped pore [42, 43], where $n=4$ is the number 142 of transferred electrons from the microelectrode per $\mathrm{O}_{2}$ molecule, $D\left(\mathrm{O}_{2}\right)=2.0 \times 10^{-5} \mathrm{~cm}^{2} \mathrm{~s}^{-1}$ [44] is the diffusion 143 coefficient of dioxygen, $r_{\mathrm{T}}=5 \mu \mathrm{m}$ is the microelectrode radius, $r_{\mathrm{S}}$ is the radius of the silicate hole, $\left[\mathrm{O}_{2}\right]_{\mathrm{S}}$ is the 144 additional concentration of dioxygen at the silicate surface, and $\zeta$ is a dimensionless factor describing the 145 decrease of dioxygen concentration as a function of the lateral distance $\Delta x=x-x_{0}$ and the vertical distance $d$ 146 from the centre of the silicate spot. Non-linear curve fitting (Fig. 3) yields the following adjustable parameters: $1474 F D r_{\mathrm{T}} c_{\mathrm{S}}=0.161 \mathrm{nA}, x_{0}=275 \mu \mathrm{m}, d=10.1 \mu \mathrm{m}, r_{\mathrm{S}}=79.9 \mu \mathrm{m}, i_{\text {offset }}=2.08 \mathrm{nA}$.

148 The fitted value of $d$ agrees well with the distance the microelectrode was retracted from the surface before 149 recording the image. The value of $r_{\mathrm{S}}$ is consistent with the $75 \mu \mathrm{m}$ diameter estimated by optical microscopy. The 150 offset current is a consequence of the presence of dioxygen traces in the electrolyte. The additional dioxygen 151 surface concentration $\left[\mathrm{O}_{2}\right]_{\mathrm{s}}$ can be estimated as $0.0417 \mathrm{mM}$, i.e. $15.4 \%$ of dioxygen concentration under air and 152 atmospheric pressure. From this value, the flux $\Omega$ of dioxygen from the silicate can be calculated [43]:

$\Omega=4 D\left(\mathrm{O}_{2}\right) r_{\mathrm{S}}\left[\mathrm{O}_{2}\right]_{\mathrm{S}}=2.66 \times 10^{-14} \mathrm{~mol} \mathrm{~s}^{-1}$

154 Although there is mass transfer resistance for dioxygen diffusion at the entrance of the pore from the gas phase 155 and at the exit from the pore to aqueous solution we supposed that is negligible as compared to that in the pore. 156 Assuming that $\mathrm{O}_{2}$ partition coefficient between silicate and aqueous solution is equal unity and uniform flux 157 through the silicate the mass-transfer coefficient $m$ for dioxygen in MTMOS-based silicate can be estimated 158 from the following equation:

$m=\frac{\Omega \cdot l}{\pi \cdot r_{\mathrm{S}}^{2} \cdot\left(\left[\mathrm{O}_{2}\right]_{\mathrm{S}}^{\prime}-\left[\mathrm{O}_{2}\right]_{\mathrm{S}}\right)}=4.66 \times 10^{-5} \mathrm{~cm}^{2} \mathrm{~s}^{-1}$

160 where $l$ is mass-transport length equal to the sample thickness and $\left[\mathrm{O}_{2}\right] \mathrm{s}$ ' is dioxygen surface concentration at the 161 back side of the sample. If one assume $\left[\mathrm{O}_{2}\right]_{\mathrm{s}^{\prime}}=2.7 \times 10^{-5} \mathrm{~mol} \mathrm{~cm}^{-3}$ (corresponding to an air-saturated aqueous 
solution [44]), the $m$ for dioxygen transport in MTMOS-based silicate would be over two times higher than the diffusion coefficient for dioxygen in water. Consequently, it can be concluded that the mass transport occurs predominately over the silicate phase as gas diffusion in an interconnected pore system of the electrode material.

Next, the CCGE electrode was examined by SECM in $\mathrm{K}_{4}\left[\mathrm{Fe}(\mathrm{CN})_{6}\right]$ aqueous solution and the feedback mode was used to visualise the local electrochemical reaction rate and the electronic conductivity of the CCGE (Fig. 4A). Although the electrode was polished the topography can still affect this image [45]. First the microelectrode was kept at $0.5 \mathrm{~V}$ in order to oxidize $\left[\mathrm{Fe}(\mathrm{CN})_{6}\right]^{4-}$. Areas of higher feedback current (darker in Fig. $4 \mathrm{~A}$ ) correspond to the locally higher electronic conductivity. After switching the microelectrode potential to $-0.4 \mathrm{~V}$, the diffusioncontrolled dioxygen reduction current at the microelectrode is recorded above the same region. Now darker areas correspond to higher reduction currents (Fig. 4B) and represent these fragments of the CCGE surface where more dioxygen reaches the electrodelelectrolyte interface. Comparison of the SECM images in Figs. 4A and 4B, reveals that areas of higher conductivity are characterised by lower dioxygen supply. Vice versa, lower conductivity areas correspond to higher dioxygen ingress. Areas with higher currents in Fig. 4A are most likely graphite microparticles providing conductivity but being impermeable for dioxygen. The high currents fragments shown in Fig. 4B are rich in silicates that provide diffusion paths for dioxygen, but have a lower conductivity. The local analysis of transport pathways for electrons and gaseous reactants in composite electrodes provides a new analytcial tool for optimising the composite structures of porous electrodes that may be important also for other gas breathing electrodes.

The catalytic activity of the CCGE with adsorbed BOx was examined by cyclic voltammetry (Fig. 5) in deaerated buffer. In this experiment dioxygen is supplied from the gas phase at the back side of the electrode. The onset of the cathodic current is observed at $0.45 \mathrm{~V}$ at a slightly higher potential than for cobalt tetraphenylporphyrin-modified CCGE (ca. $0.4 \mathrm{~V}$ vs. $\mathrm{Ag} \mid \mathrm{AgCl}$ at $\mathrm{pH}$ 0) [5]. The cathodic current is proportional to the dioxygen partial pressure at the back side of the electrode. (Fig. 5, lines 2 and 3). This dependence observed at constant total pressure indicates that transport of the dioxygen from the gas phase affects the current density of dioxygen bioelectroreduction. Interestingly, almost no hysteresis is observed in the voltammograms. This is different than observed for analogous electrode operating in dioxygen-saturated solution [9]. This means that the mass transport through the CCGE can maintain a steady state mass transport. (see ref. [12]). We had already observed earlier that $\mathrm{H}_{2} \mathrm{O}_{2}$ as a possible side product can be formed at CCGE, but only if the potential is below $0.05 \mathrm{~V}$ vs. $\mathrm{Ag} \mid \mathrm{AgCl}$ at $\mathrm{pH} 5$ and dioxygen reduction occurs also at the carbon particles [9]. At higher potentials at which all the oxygen reduction is catalyzed by $\mathrm{BOx}, \mathrm{no}_{2} \mathrm{O}_{2}$ can be detected by SECM [9].

Finally, the CCGE was tested as cathode in a zinc-dioxygen primary cell [21-23]. A non-protected zinc wire could be used as anode. Typical oxygen corrosion of zinc was avoided by using an essentially oxygen-free electrolyte. Current density-voltage and power density-voltage characteristics are presented in Fig 6A and 6B respectively. The highest open-circuit voltage $(1.095 \mathrm{~V})$ was recorded when pure dioxygen was supplied to the back side of the biocathode. The highest power density $\left(41.3 \mu \mathrm{W} \mathrm{cm}{ }^{-2}\right)$ was recorded under the same conditions at a cell voltage of $0.585 \mathrm{~V}$. Clearly, the cell efficiency strongly depends on the external dioxygen partial pressure.

\section{Conclusions}

It has been shown that a carbon ceramic electrode composed of hydrophobic sol-gel processed silicate, carbon microparticles and carbon nanoparticles exhibits bioelectrocatalysis of dioxygen reduction after adsorption of bilirubin oxidase. When its back side is opened to a dioxygen-containing gas phase it can be operated as gas electrode. The bioelectrocatalytic current is proportional to the partial pressure of dioxygen present in gas phase. The dioxygen mass transport rate through the porous carbon ceramic electrode consisiting of MTMOS-based silicate is over two times higher than dioxygen diffusion in aqueous solution. However, the catalytic activity does not differ much from the analogous CCE operated in dioxygen-containing aqueous solution [9]. The construction of the electrode was not optimised and its efficiency as biocathode can be further improved by decreasing its thickness (film electrode). It is also clear that enzyme adsorption is not the best method from the point of view of electrode stability and enzyme loading and other methods of enzyme immobilization will be tested. However, it is important to say that adsorption of copper oxidoreductases on carbon materials provide 
211 favourable conditions for mediatorless catalysis [11, 28, 46-48]. The zinc-dioxygen cell efficiency is 212 proportional to the partial pressure of dioxygen applied to the back side of CCGE. This feature suggests its 213 application in self-powered dioxygen biosensors.

214

\section{Acknowledgements}

216 We thank Dr. Yuriy Stepanenko and Bartlomiej Bialkowski (Institute of Physical Chemistry, Polish Academy of 217 Sciences, Warsaw, Poland) for their help with the laser-assisted sample preparation. Financial support from the 218 Polish Ministry of Science and Higher Education (N N204 161936) is gratefully acknowledged. The generous 219 gift of bilirubin oxidase from Amano Enzyme Europe Ltd. is greatly appreciated. 
[1] M. Tsionsky, G. Gun, V. Glezer, O. Lev, Anal. Chem. 1994, 66, 1747.

225

226

227

228

229

230

231

232

233

234

235

236

237

238

239

240

241

242

243

244

245

246

247

248

249

250

251

252

253

254

255

256

257

[2] L. Rabinovich, O. Lev, Electroanalysis 2001, 13, 265.

[3] J. Gun, M. Tsionsky, L. Rabinovich, Y. Golan, I. Rubinstein, O. Lev, J. Electroanal. Chem. 1995, 395, 57.

[4] M. Tsionsky, O. Lev, Anal. Chem. 1995, 67, 2409.

[5] M. Tsionsky, O. Lev, J. Electrochem. Soc. 1995, 142, 2132.

[6] L. Rabinovich, O. Lev, G. A. Tsirlina, J. Electroanal. Chem. 1999, 466, 45.

[7] L. Rabinovich, V. Glezer, Z. B. Wu, O. Lev, J. Electroanal. Chem. 2001, 504, 146.

[8] W. Nogala, M. Burchardt, M. Opallo, J. Rogalski, G. Wittstock, Bioelectrochemistry 2008, 72, 174.

[9] W. Nogala, A. Celebanska, K. Szot, G. Wittstock, M. Opallo, Electrochim. Acta 2010, doi:10.1016/j.electacta.2010.05.007,

[10] W. Nogala, E. Rozniecka, I. Zawisza, J. Rogalski, M. Opallo, Electrochem. Commun. 2006, $8,1850$.

[11] B. Haghighi, A. Rahmati-Panah, S. Shleev, L. Gorton, Electroanalysis 2007, 19, 907.

[12] R. Kontani, S. Tsujimura, K. Kano, Bioelectrochemistry 2009, 76, 10.

[13] A. P. Borole, S. LaBarge, B. A. Spott, J. Power Sources 2009, 188, 421.

[14] A. Habrioux, G. Merle, K. Servat, K. B. Kokoh, C. Innocent, M. Cretin, S. Tingry, J. Electroanal. Chem. 2008, 622, 97.

[15] W. Gellett, J. Schumacher, M. Kesmez, D. Le, S. D. Minteer, J. Electrochem. Soc. 2010, 157, B557.

[16] I. Willner, Y. M. Yan, B. Willner, R. Tel-Vered, Fuel Cells 2009, 9, 7.

[17] M. J. Moehlenbrock, S. D. Minteer, Chem. Soc. Rev. 2008, 37, 1188.

[18] E. Nazaruk, S. Smolinski, M. Swatko-Ossor, G. Ginalska, J. Fiedurek, J. Rogalski, R. Bilewicz, J. Power Sources 2008, 183, 533.

[19] M. Burchardt, G. Wittstock, Bioelectrochemistry 2008, 72, 66.

[20] Y. M. Yan, I. Baravik, R. Tel-Vered, I. Willner, Adv. Mater. 2009, 21, 4275.

[21] K. Szot, W. Nogala, J. Niedziolka-Jonsson, M. Jonsson-Niedziolka, F. Marken, J.

Rogalski, C. N. Kirchner, G. Wittstock, M. Opallo, Electrochim. Acta 2009, 54, 4620.

[22] A. Heller, Anal. Bioanal. Chem. 2006, 385, 469.

[23] M. Smolander, H. Boer, M. Valkiainen, R. Roozeman, M. Bergelin, J. E. Eriksson, X. C. Zhang, A. Koivula, L. Viikari, Enzyme Microb. Technol. 2008, 43, 93.

[24] W. Shin, J. Lee, Y. Kim, H. Steinfink, A. Heller, J. Am. Chem. Soc. 2005, 127, 14590.

[25] S. Murao, N. Tanaka, Agric. Biol. Chem. 1981, 45, 2383.

258 [26] E. I. Solomon, U. M. Sundaram, T. E. Machonkin, Chem. Rev. 1996, 96, 2563.

259 [27] P. Ramirez, N. Mano, R. Andreu, T. Ruzgas, A. Heller, L. Gorton, S. Shleev, Biochim.

260

261

262

263

264

265

266

267

268

269

Biophys. Acta 2008, 1777, 1364.

[28] S. Tsujimura, Y. Kamitaka, K. Kano, Fuel Cells 2007, 7, 463.

[29] N. Mano, H. H. Kim, Y. C. Zhang, A. Heller, J. Am. Chem. Soc. 2002, 124, 6480.

[30] A. J. Bard, F.-R. F. Fan, J. Kwak, O. Lev, Anal. Chem. 1989, 61, 132.

[31] G. Wittstock, M. Burchardt, S. E. Pust, Y. Shen, C. Zhao, Angew. Chem. Int. Ed. 2007, 46, 1584.

[32] J. Strutwolf, J. Zhang, A. L. Barker, P. R. Unwin, Phys. Chem. Chem. Phys. 2001, 3, 5553.

[33] S. Cannan, J. Zhang, F. Grunfeld, P. R. Unwin, Langmuir 2004, $20,701$.

[34] M. Carano, K. B. Holt, A. J. Bard, Anal. Chem. 2003, 75, 5071.

$270 \quad[35]$

H. Shiku, T. Saito, C. C. Wu, T. Yasukawa, M. Yokoo, H. Abe, T. Matsue, H. 
Yamada, Chem. Lett. 2006, 35, 234.

[36] M. Gonsalves, A. L. Barker, J. V. Macpherson, P. R. Unwin, D. O'Hare, C. P. Winlove, Biophys. J. 2000, 78, 1578.

[37] J. V. Macpherson, D. OHare, P. R. Unwin, C. P. Winlove, Biophys. J. 1997, 73, 2771.

[38] T. Yasukawa, Y. Kondo, I. Uchida, T. Matsue, Chem. Lett. 1998, 767.

[39] T. Kaya, Y. S. Torisawa, D. Oyamatsu, M. Nishizawa, T. Matsue, Biosens. Bioelectron. 2003, 18, 1379.

[40] C. Kranz, M. Ludwig, H. E. Gaub, W. Schuhmann, Adv. Mater. 1995, 7, 568.

[41] G. Wittstock, T. Asmus, T. Wilhelm, Fresenius J. Anal. Chem. 2000, 367, 346.

[42] Y. Saito, Rev. Polarogr. 1968, 15, 177.

[43] B. D. Bath, R. D. Lee, H. S. White, E. R. Scott, Anal. Chem. 1998, 70, 1047.

[44] Y. Shen, M. Träuble, G. Wittstock, Anal. Chem. 2008, 80, 750.

[45] W. Nogala, K. Szot, M. Burchardt, M. Jönsson-Niedziolka, J. Rogalski, G. Wittstock, M. Opallo, Bioelectrochemistry 2010, 79, 101.

[46] C. F. Blanford, R. S. Heath, F. A. Armstrong, Chem. Commun. 2007, 1710.

[47] A. Lesniewski, J. Niedziolka-Jonsson, C. Rizzi, L. Gaillon, J. Rogalski, M. Opallo, Electrochem. Commun. 2010, 12, 83.

[48] K. Szot, J. Watkins, S. Bull, F. Marken, M. Opallo, Electrochem. Commun. 2010, 12, 737. 

1

\section{Figure Captions}

293 Scheme 1: A scheme of carbon ceramic gas electrode for bioelectrocatalytic reduction of dioxygen supplied 294 from the gas phase.

295 Fig. 1: Optical micrograph of a hole in a PS plate filled with MTMOS-based silicate.

296 Fig. 2: (A) SECM feedback image of a hole in PS plate filled with MTMOS-based silicate; $E_{\mathrm{T}}=+0.5 \mathrm{~V}$, (B) 297 SECM generation-collection mode image of dioxygen permeability through silicate; $E_{\mathrm{T}}=-0.4 \mathrm{~V}$. Other 298 parameters for both experiments: $r_{\mathrm{T}}=5 \mu \mathrm{m}, R G \approx 32, d=10 \mu \mathrm{m}$, horizontal scan rate $v_{\mathrm{T}}=50 \mu \mathrm{m} \mathrm{s}^{-1}$, electrolyte 299 was deaerated $0.1 \mathrm{mM} \mathrm{K}_{4}\left[\mathrm{Fe}(\mathrm{CN})_{6}\right]$ in $0.1 \mathrm{M}$ phosphate buffer, $\mathrm{pH} 5$.

300 Fig. 3: Flux of dioxygen emerging from individual hole filled with MTMOS-based silicate. Flux values are 301 obtained from the extracted profile along the white line in the inset and fits to Eqs. $(2,3)$. Dotted line 302 experimental data, solid line - fitted curve. For more details see the text and the caption of Fig. 2.

303 Fig. 4: (A) SECM feedback mode image of a CCGE and its schematic representation; $E_{\mathrm{T}}=+0.5 \mathrm{~V}$, (B) SECM 304 generation-collection mode image of the measurement of dioxygen permeability through the CCGE and its 305 schematic representation. $E_{\mathrm{T}}=-0.4 \mathrm{~V}$. Other parameters for both experiments: $r_{\mathrm{T}}=5 \mu \mathrm{m}, R G \approx 6.8, d \approx 15 \mu \mathrm{m}$, $306 v_{\mathrm{T}}=25 \mu \mathrm{m} \mathrm{s}^{-1}$, electrolyte was deaerated $1 \mathrm{mM} \mathrm{K}_{4}\left[\mathrm{Fe}(\mathrm{CN})_{6}\right]$ in $0.1 \mathrm{M}$ phosphate buffer, $\mathrm{pH} 5$.

307 Fig. 5: CVs of BOx modified and CNP-enriched CCGE in deaerated $0.1 \mathrm{M}$ phosphate buffer, pH 5. Gaseous 308 dioxygen was supplied to the back side of the CCGE at various partial pressures: 1) - $0 \mathrm{~atm}, 2)-0.21 \mathrm{~atm}, 3)-$ $3091 \mathrm{~atm}$. Scan rate: $1 \mathrm{mV} \mathrm{s}^{-1}$.

310 Fig. 6: Current-voltage (A) and power-voltage (B) characteristics of zinc-dioxygen cell consisting of bare zinc 311 anode and BOx modified CNP-enriched CCGE in deaerated 0.1 M phosphate buffer, pH 5. Gaseous dioxygen 312 was supplied to the back side of the electrode at various partial pressures: 1) $-0.21 \mathrm{~atm}, 2)-1 \mathrm{~atm}$. Each data 313 point was recorded $100 \mathrm{~s}$ after a galvanostatically controlled current flow had been started. 


\section{Scheme $1 \ldots$}

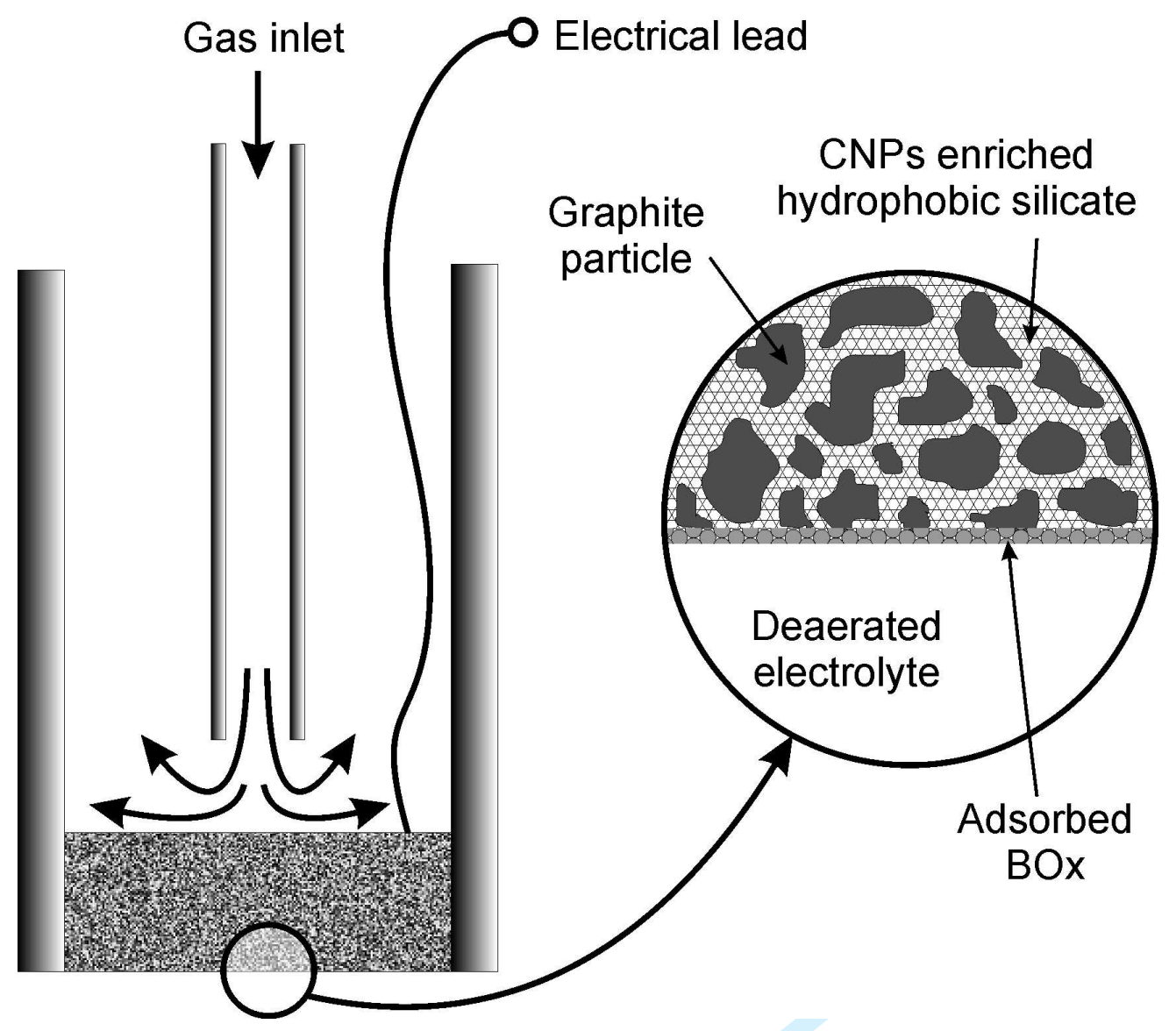




\section{Page 11 of 16}

\section{Fuel Cells}

Fig.1...

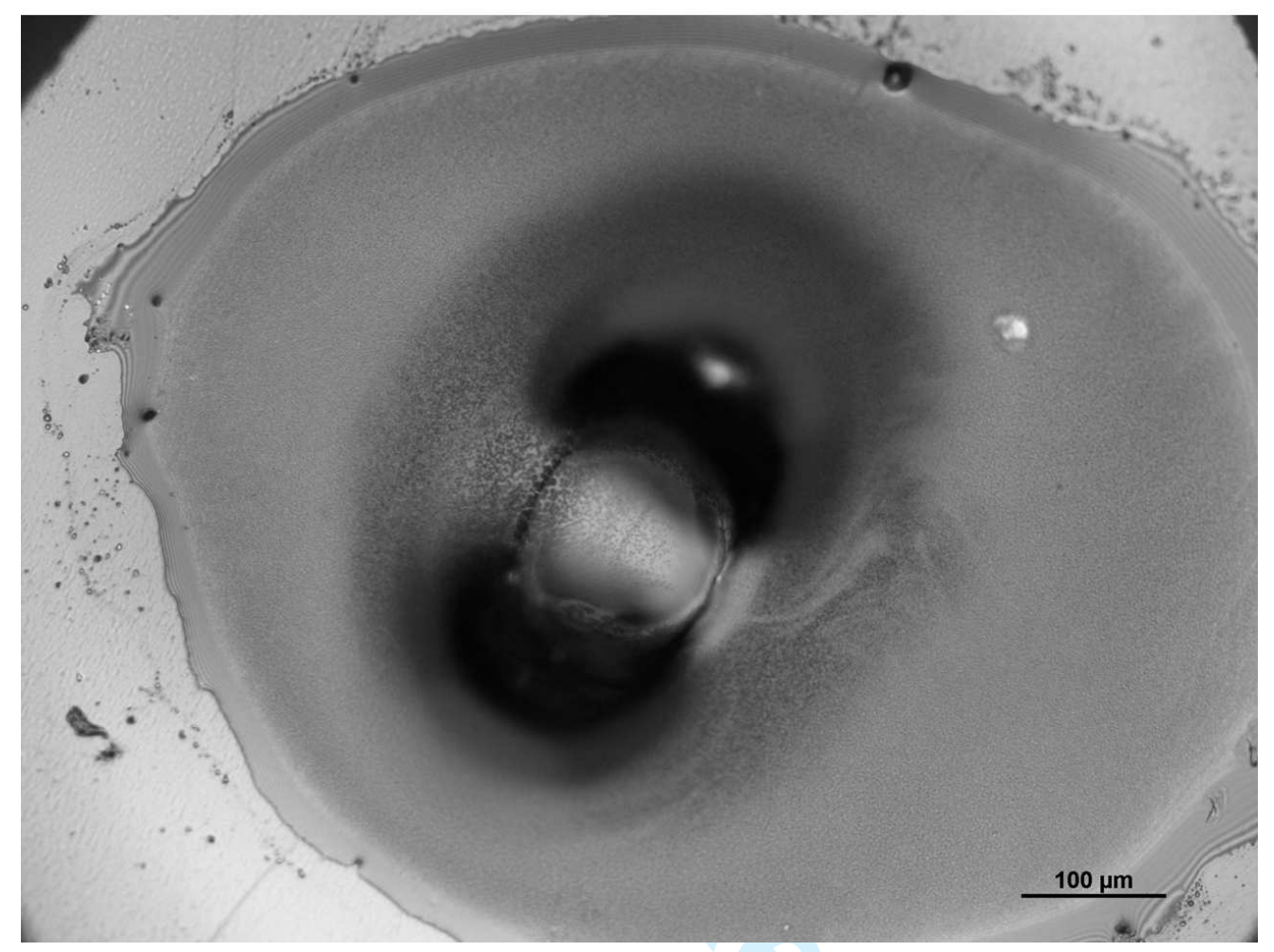


Fig.2...
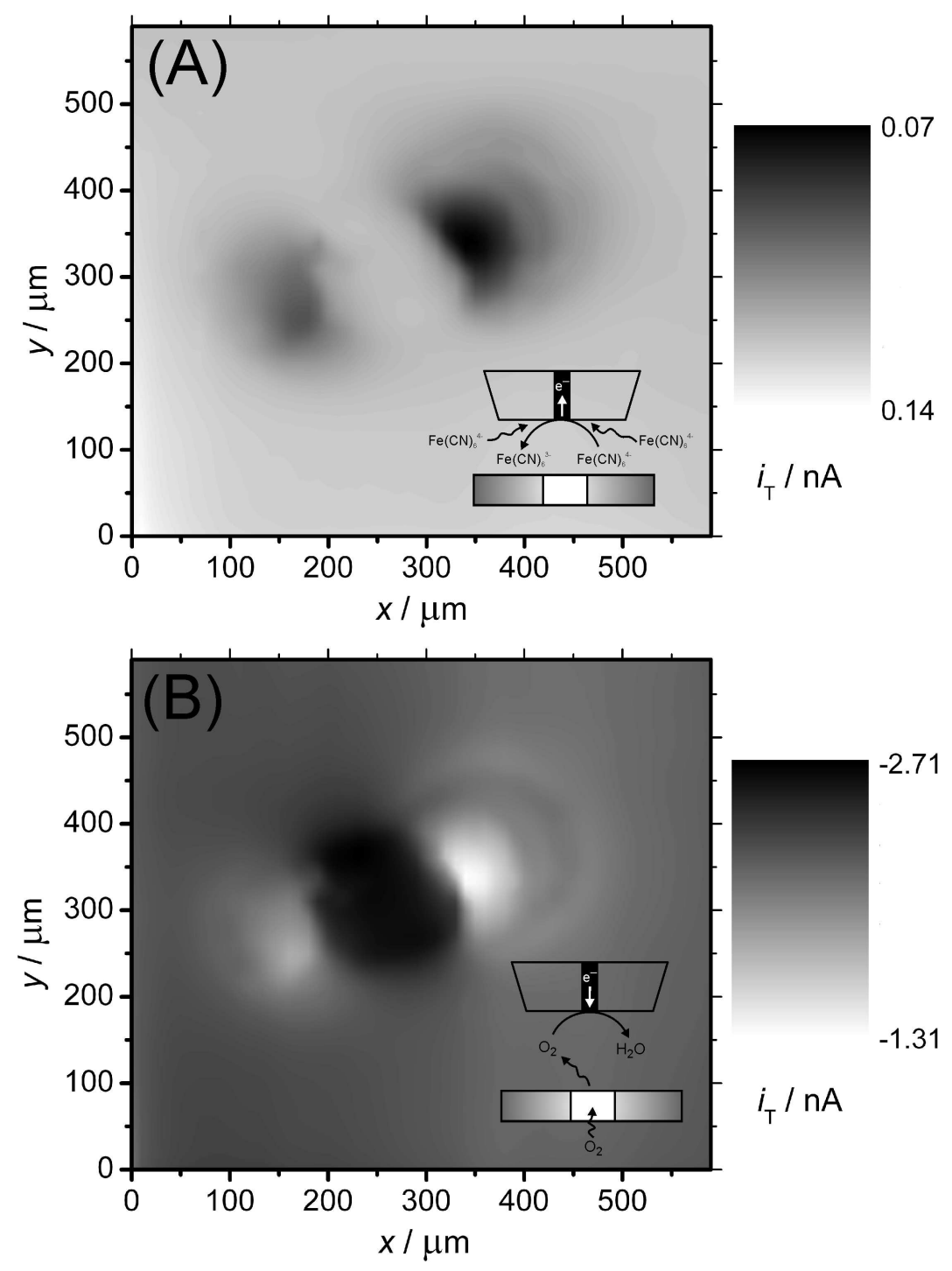
Fig.3...

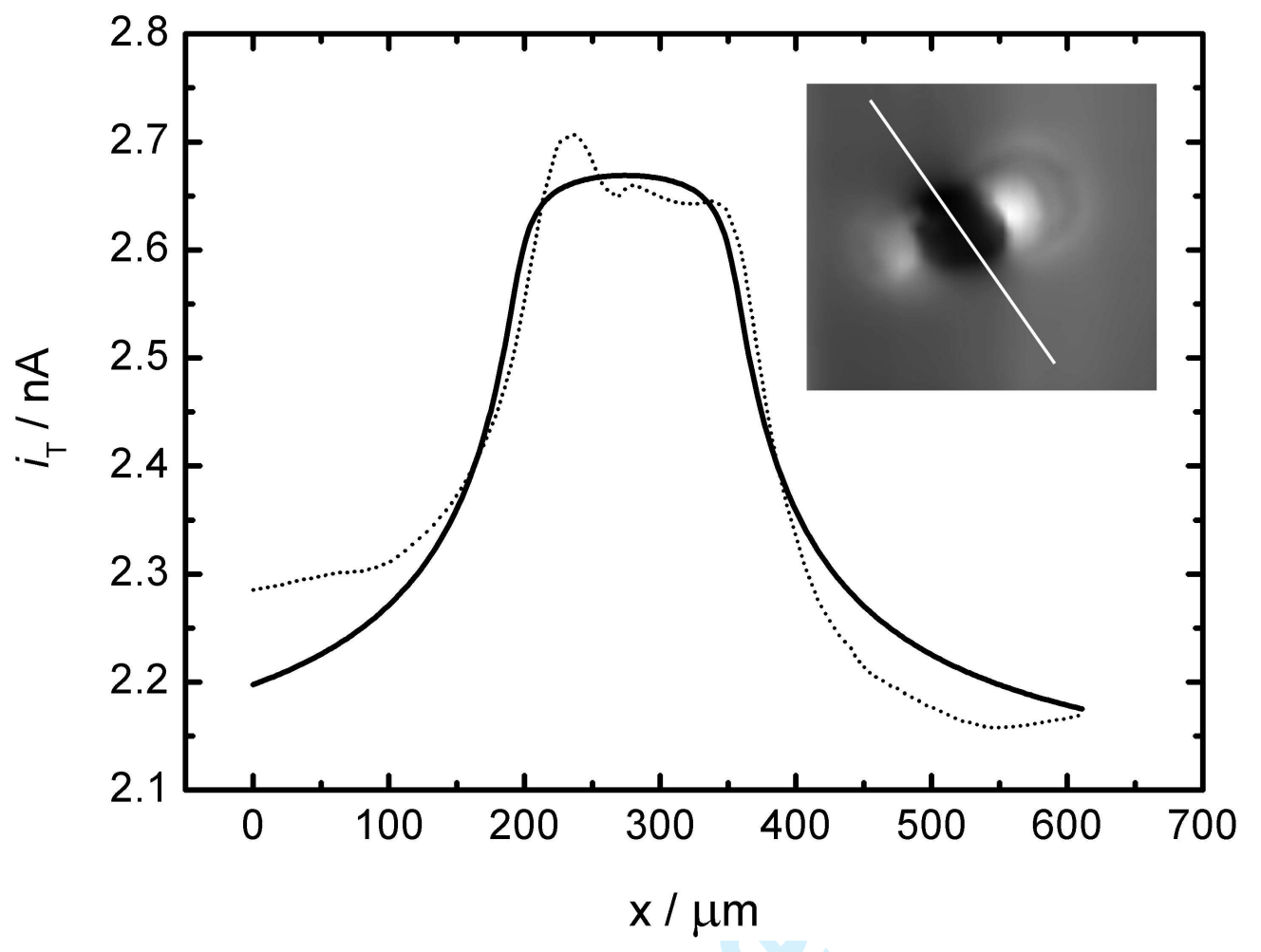


Fig. $4 \ldots$
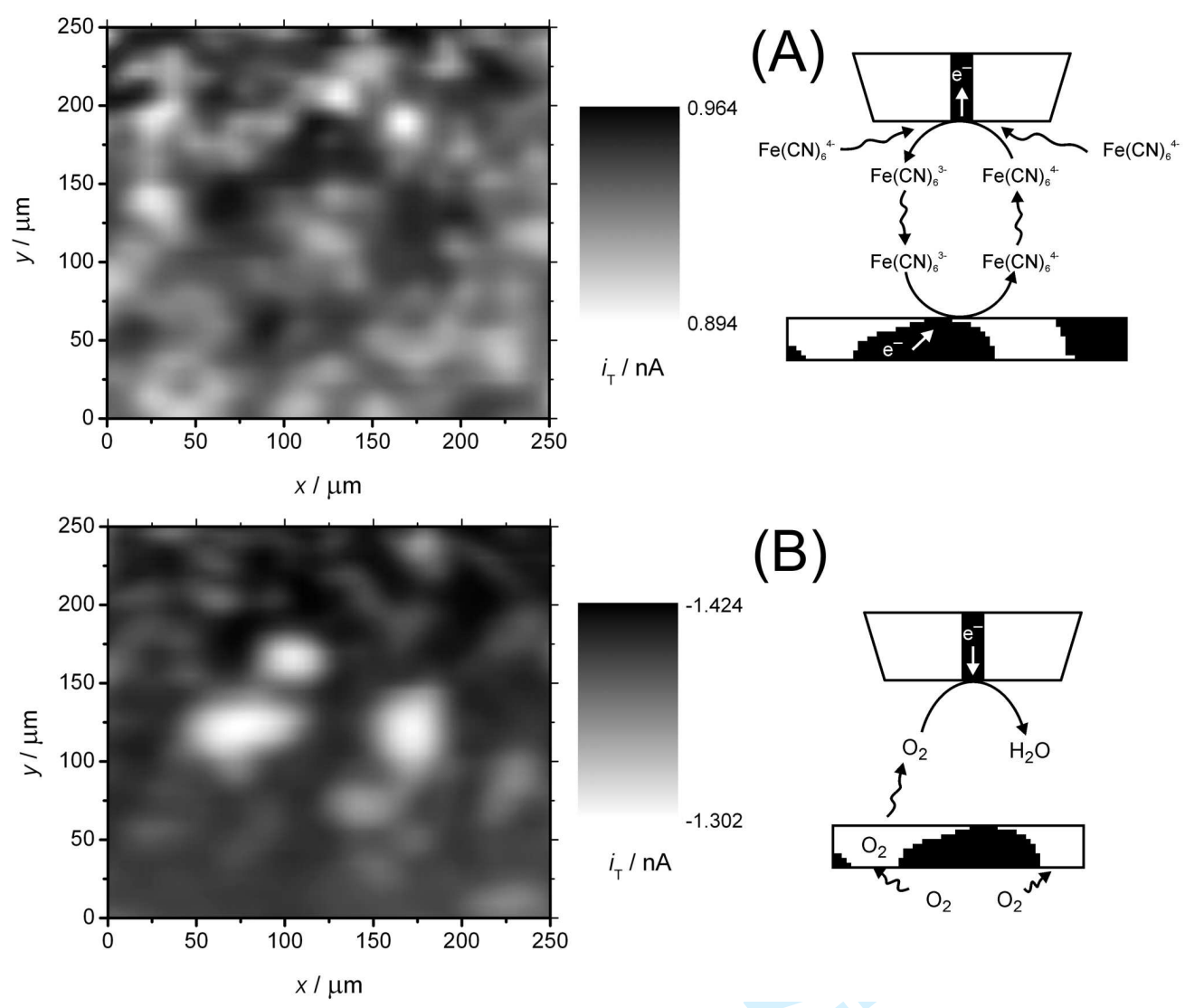

37

38

39

40

41

42

43

44

45

46

47

48

49

50

51

52

53

54

55

56

57

58

59

60 
Fig.5...

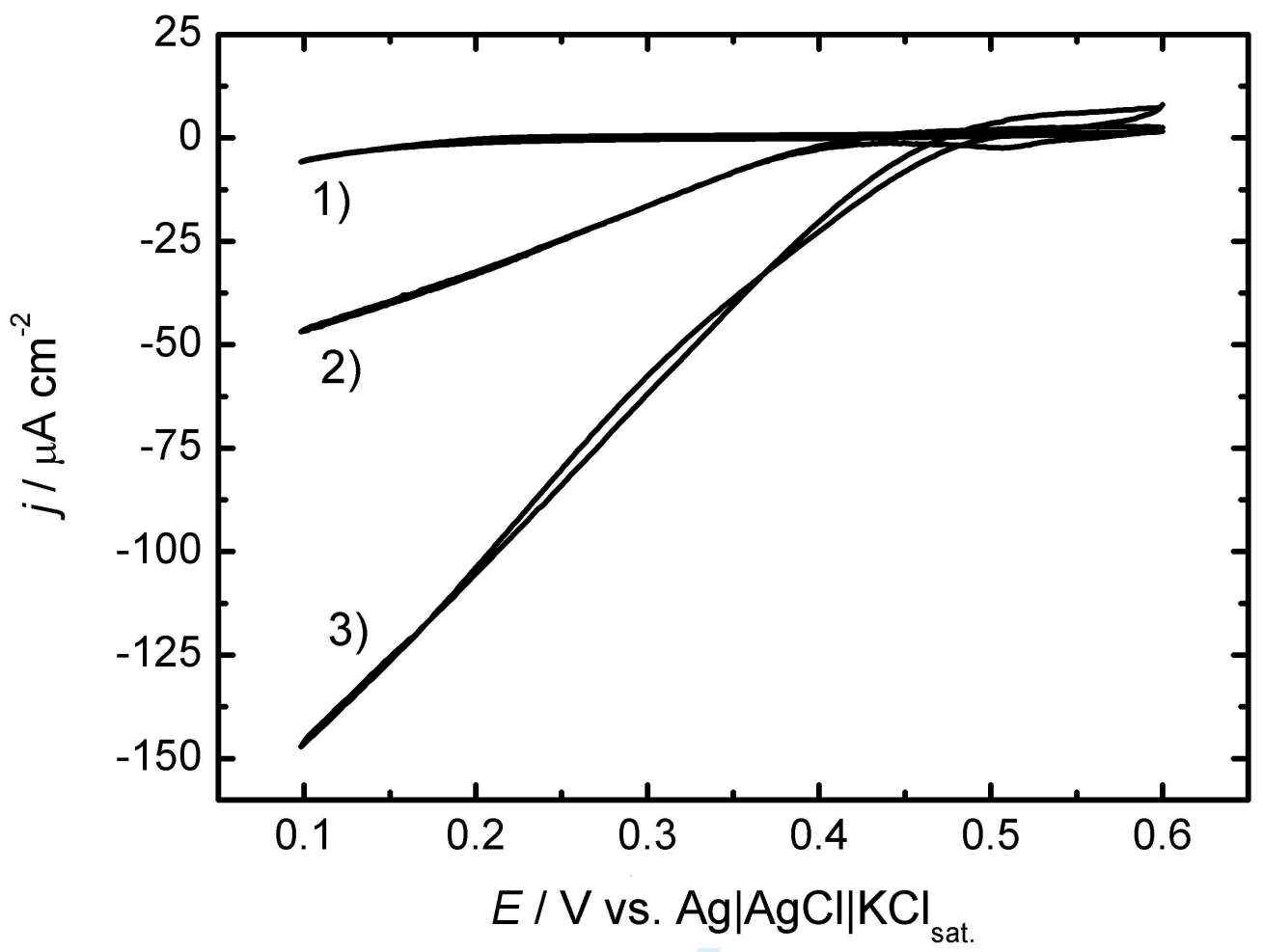


Fig.6...
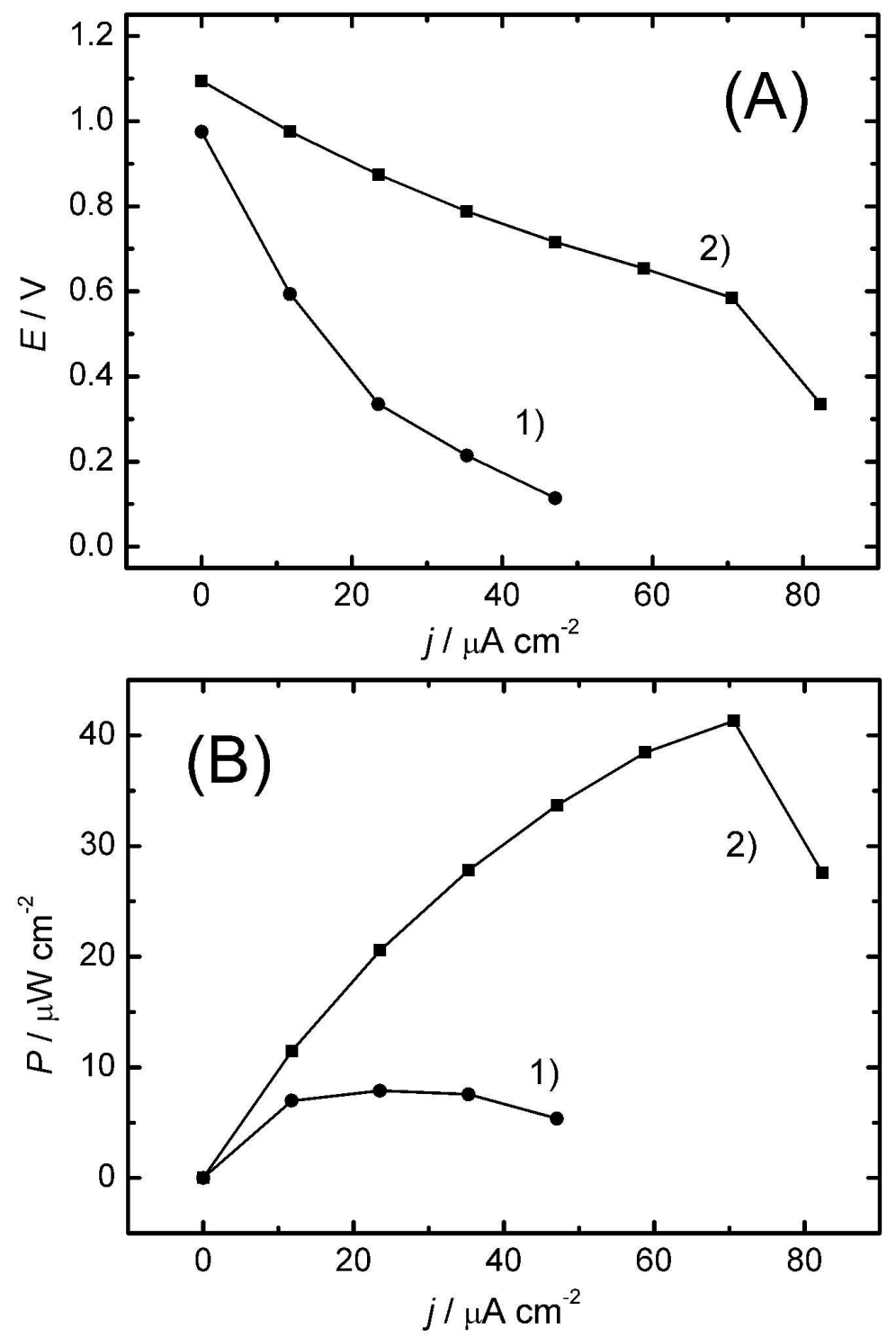

Wiley-VCH 